\title{
ANALISIS PENERAPAN PSAK 34 DALAM PENGAKUAN PENDAPATAN PERUSAHAAN JASA KONTRUKSI PADA PT ARTERI CIPTA RENCANA
}

\author{
Lola Venna Pahlevi \\ Universitas Muslim Indonesia Makassar \\ Email: lolavenna12@yahoo.co.id \\ Ratna Sari \\ Universitas Muslim Indonesia Makassar \\ Email: ratnasari@gmail.com \\ Hamzah Ahmad \\ Universitas Muslim Indonesia Makassar \\ Email: hamzahahmad@gmail.com
}

\begin{abstract}
Abtsrac
The aims of this research are to analyze the application of work contracts and the recognition of revenue for construstion service companies in accordance with PSAK 34 at PT Arteri Cipta Rencana. The data required in this study is secondary data, namely the financial statements of PT Arteri Cipta Rencana project for the period 2017-2019. Methods of data collection through interviews, observation and documentary. Data analysis techniques used by qualitative analysis. This result of this research show that that the implementation of PSAK 34 at PT Arteri Cipta Rencana had executed project contracts sequentially in accordance with the prevailing tender regulations and realized the budget appropriately. The recognition of income and expenses carried out by PT Arteri Cipta Rencana is in accordance with PSAK 34 where revenue recognition for construction contracts is carried out using the completed contract method in the short-term period in the 2016-2018 financial statements. This is in accordance with PSAK 34 applicable in Indonesia. Short-term projects using the completed contract method minimize the risk of errors in estimating the specified value. The financial statements are considered to have met the criteria for the quality of financial reports well.
\end{abstract}

Keyword: PSAK 34, Construction Company and Revenue Recognition

\begin{abstract}
Abstrak
Penelitian ini bertujuan untuk menganalisis penerapan kontrak kerja dan pengakuan pendapatan perusahaan jasa kontruksi sesuai dengan PSAK 34 pada PT Arteri Cipta Rencana. Data yang digunakan dalam penelitian ini adalah data sekunder yaitu laporan keuangan proyek PT Arteri Cipta Rencana periode 2017 - 2019. Metode pengumpulan data melalui wawancara, observasi dan dokumentasi. Teknik analisis data menggunakan analisis kualitatif. Hasil penelitian menunjukkan bahwa penerapan PSAK 34 pada PT Arteri Cipta Rencana telah menjalankan kontrak proyek dengan berurutan sesuai dengan peraturan tender yang berlaku dan merealisaikan anggaran dengan tepat. Pengakuan pendapatan dan beban yang dilakukan PT Arteri Cipta Rencana telah sesuai dengan PSAK 34 dimana pengkuan pendapatan atas kontrak kontruksi dilakukan dengan menggunakan metode kontrak selesai pada periode jangka pendek pada laporan keuangan 2016 2018. Hal ini telah sesuai dengan PSAK 34 yang berlaku di Indonesia. Proyek jangka pendek dengan menggunakan metode kontrak selesai meminimalis adanya resiko kesalahan dalam melakukan estimasi terhadap nilai yang ditentukan. Laporan keuangan dianggap telah memenuhi kriteria kualitas laporan keuangan dengan baik.
\end{abstract}

Kata kunci: PSAK 34, Perusahaan Kontruksi dan Pengakuan Pendapatan 


\section{PENDAHULUAN}

Dewasa ini perkembangan perusahaan di Indonesia sangat signifikan yang didorong oleh beberapa faktor seperti pesatnya pertumbuhan pasar. Perusahaan kontruksi adalah salah satu perusahaan yang berkembang saat ini. Tumbuh kembang proyek pembangunan terjadi dimana-mana, di kota besar maupun kota kecil. Adanya proyek seperti pusat pembelanjaan, hotel dan sarana transportasi merupakan faktor permintaan dari masyarakat yang saat ini sesuai dengan pola hidup mereka sehari-hari disertai dengan aktivitas yang beragam dan semakin meningkat menuntut mereka untuk beradaptasi (Riswan, 2014).

Menurut Suwarti (2009) salah satu perjanjian yang sering terjadi dalam hukum perdata adalah perjanjian pemborongan dimana perjanjian atau kontrak pekerjaan tersebut yang sekarang disebut dengan kontrak kerja konstruksi harus memenuhi kaidah kaidah dasar perjanjian dan kewajiban dalam memenuhi kelayakan suatu perjanjian. Perjanjian kerja konstruksi termasuk perjanjian yang mengandung resiko yang tinggi yaitu resiko keselamatan umum dan tertib bangunan, maka perjanjian kerja konstruksi ini dapat ditempatkan pada suatu perjanjian yang standar.

Perjanjian standar terbentuk berdasarkan standar yang berlaku yang ditetapkan oleh Departemen Pekerjaan Umum. Selanjutnya pelaksanaan kontrak kerja antara antara para pihak harus memperhatikan berlakunya ketentuan perjanjian kereja kontruksi dalam melakukan pekerjaan, ketentuan dalam perjanjian tersebut pada umumnya mengatur tentang hak-hak dan kewajiban pemborong, dan yang harus lebih diperhatikan lagi adalah dalam pembuatan kontrak kerja, mulainya kontrak kerja, pelaksanaan kontrak kerja dan berakhirnya kontrak kerja, yaitu fase setelah adanya pelulusan sampai dengan penyerahan pekerjaan.

Pengikatan dalam bentuk kontrak konstruksi ini menjadi sangat penting untuk dilakukan mengingat konstruksi dewasa ini merupakan bidang usaha jasa yang banyak diminati oleh anggota masyarakat di berbagai tingkatan, sebagaimana dapat dilihat dari semakin besarnya jumlah perusahaan/badan usaha yang bergerak di bidang usaha penyedia jasa konstruksi. Peningkatan jumlah perusahaan atau badan usaha ini belum diikuti dengan pemahaman oleh perusahaan atau badan usaha terkait dengan landasan filosofis hubungan kontraktual antara pemberi jasa konstruksi dengan penyedia jasa konstruksi dan pengawas jasa konstruksi, prinsip dan norma hukum tahap pembentukan kontrak konstruksi, prinsip dan norma hukum tahap pelaksanaan kontrak konstruksi. Termasuk juga kepatuhan/ketaatan para pihak di dalam pemenuhan kewajiban serta pemenuhan terhadap ketentuanketentuan yang telah disepakati kedua belah pihak di dalam kontrak

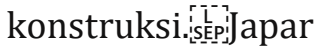
mengungkapkan bahwa agara terciptanya penyelenggaraan jasa kontruksi yang memenuhi asas kejujuran dan keadilan, manfaa, keserasian, keseimbangan, kemandirian, keterbukaan, kemitraan dan keselamatan demi kepentingan masyarakat, bangsa dan negara.

Perkembangan suatu perusahaan dapat dilihat dari kondisi keuangan perusahaan. Kondisi keuangan suatu perusahaan dapat diketahui melalui 
laporan keuangan perusahaan.

Perusahaan harus menyusun laporan keuangannya secara periode untuk mengetahui perkembangan perusahaannya. Laporan keuangan merupakan catatan informasi suatu perusahaan pada suatu periode akuntansi yang harusnya dapat digunakan untuk menggambarkan kinerja entitas tersebut (Fajrianto, 2019). Laporan keuangan yang baik mampu menjadi dasar untuk pengambilan keputusan yang tepat bagi perusahaan.

Untuk dapat menghasilkan laporan keuangan yang berkualitas, perusahaan kontruksi disyaratkan memiliki sistem akuntansi. Kualiatas laporan keuangan dalam perusahaan sangat memepengaruhi oleh seberapa bagus sistem akuntansi yang digunakan. Sistem Akuntansi merupakan serangkaian prosedur dan tahap- tahap proses yang harus diikuti mulai dari pengumpulan dan pengorganisasian data-data, pengolahan data menjadi informasi serta penyajian laporan keuangan (Maulinda, 2019). Dalam menyusun laporan keuangan yang wajar ada beberapa faktor yang mempengaruhinya salah satunya komponen laporan keuangan yaitu laporan laba rugi dimana laporan tersebut merupakan dasar penting untuk mengetahui kinerja keuangan perusahaan yang mencakup pendapatan dan beban.

Pendapatan merupakan indikator untuk pembentukan laba, oleh karena itu pendapatan diukur secara wajar sesuai prinsip pengakuan pendapatan untuk diterapkan guna mengukur pendapatan yang diterima sebenarnya oleh perusahaan. Dimana pendapatan merupakan kegiatan pokok juga merupakan komponen yang akan diperbandingkan dalam laporan keuangan dan disajikan sesuai Standar Akuntansi Keuangan. Pendapatan juga salah satu modal kerja yang paling likuiditas karena kejadian yang menyebabkan naiknya nilai asset mengakibatkan pendapatan menjadi sasaran yang paling mudah untuk disalah gunakan (Lumingkewas, 2013).

Pada perusahaan kontruksi, terdapat hal spesifik dalam menentukan waktu dan pendapatan, yaitu dimana pendapatan harus diakui dan dilaporkan. Pada umumnya pendapatan diakui pada saat pekerjaan selesai. Namum menurut standar akuntansi keuangan, perusahaan kontruksi dimungkinkan untuk mengakui pendapatan selama berlangsungnya produksi sesuai dengan tahap waktu dimana pendapatan harus diakui dan dilaporkan, maka timbul dua metode pengakuan pendapatan pada perusahaan kontruksi, yaitu metode kontrak selesai dan metode persentase penyelesaian. Apabila perusahaan menggunakan metode kontrak selesai, maka pendapatan diakui pada ssat pekerjaan telah selesai.

Sedangkan jika perusahaan menggunakan metode persentase penyelesaian, maka pendapatan dapat ditaksir pada ssat proses produksi berlangsung. Farmuzi dkk (2015) menjelaskan bahwa penerapan metode pengakuan pendapatan mempunyai pengaruh dalam perhitungan rugi dan laba perusahaan. Apabila penerapan metode pengakuan pendapatan tidak tepat maka akan menyajikan laporan keuangan yang tidak mencerminkan kinerja dan performance perusahaan. Perlakuan akuntansi pendapatan yang berbeda dengan perusahaan lainnya karena sifat dari aktivitas yang dilakukan pada kontrak konstruksi, tanggal saat 
aktivitas kontrak konstruksi mulai dilakukan dan tanggal saat aktivitas tersebut diselesaikan biasanya jatuh pada periode akuntansi yang berlainan. Perlakuan akuntansi pendapatan perusahaan konstruksi berhubungan dengan kontrak konstruksi.

Secara konseptual, informasi akuntansi harus dapat memenuhi kriteria antara biaya dan manfaat. Salang satu bagian terpenting dalam lapotran keuangan adalah pendapatan. Perlakuan yang tepat atas akuntansi dalam mengakui pendapatan dan beban sangat berpengaruh terhadap kewajaean yang dihasilkan dalam laporan laba rugi. Menurut Nurianti (2013), persoalan utama dalam perusahaan jasa konstruksi adalah pengakuan pendapatan kontrak pada periode di mana pekerjaan konstruksi tersebut dilaksanakan. Pengakuan pendapatan pada perusahaan jasa konstruksi memerlukan waktu lebih dari satu periode akuntansi, metode pengakuan pendapatannya pun berbeda dengan perusahaan lain yang operasinya kurang dari satu periode akuntansi.

Metode pengakuan yang diterapkan perusahaan konstruksi memegang posisi yang penting dalam kerangka akuntansi karena mempengaruhi secara langsung laba rugi yang timbul akibat aktivitas perusahaan selama periode tertentu. Metode pengakuan pada perusahaan konstruksi ada dua yaitu metode kontrak selesai (completed contract method) dan metode persentase penyelesaian (percentage of completation method). Metode kontrak selesai mengakui pendapatan dan laba kotor perusahaan hanya pada saat kontrak selesai, dan metode persentase penyelesaian mengakui pendapatan dan laba kotor perusahaan sesuai dengan kemajuan perusahaan dalam menyelesaikan kontrak.

Dalam PSAK 34 revisi 2010 menjelaskan tahap penyelesaian suatu kontrak dapat ditentukan dalam berbagai cara. Entitas menggunakan metode yang mengukur secara andal pekerjaan yang dilakukan bergantung pada sifat kontrak. Jika tahap penyelesaian ditentukan dengan memerhatikan biaya kontrak yang terjadi pada saat ini, maka hanya biaya kontrak yang mencerminkan pekerjaan yang dilaksanakan dimasukkan ke biaya. Selama tahap awal suatu kontrak sering terjadi hasil kontrak tidak dapat diestimasi secara andal. Walaupun demikian, dimungkinkan entitas akan memulihkan biaya kontrak yang terjadi. Oleh karena itu, pendapatan kontrak diakui hanya sepanjang biaya yang terjadi diharapkan dapat dipulihkan.

Thoyyibah (2017) mengungkapkan bahwa perusahaan kontruksi memiliki karakteristik yang khas, dimana pembangunan proyek tidak semuanya terselesaikan dalam satu periode akuntansi dan pada umumnya pembangunan dilakukan di pertengahan tahun. Sehingga diperlukan beberapa metode yang dapat digunakan oleh perusahaan kontruksi untuk mengakui pendapatannya. Dalam PSAK No. 34 Pendapatan kontrak diukur pada nilai wajar dari imbalan yang diterima atau yang akan diterima. Pengukuran pendapatan kontrak dipengarui oleh bermacam-macam ketidakpastian yang tergantung pada hasil dari peristiwa di masa yang akan datang. Estimasi seringkali harus direvisi sesuai dengan realisasi dan hilangnya ketidakpastian. Oleh karena itu, jumlah pendapatan kontrak dapat meningkat atau menurun 
dari suatu periode dengan periode berikutnya.

Terdapat beberapa penelitian yang dilakukan oleh peneliti-peneliti sebelumnya mengenai kontrak kerja dan pengakuan pendapatan perusahaan kontruksi oleh Pramurti (2016) mengungkapakan bahwa manajer perusahaan telah mencatat jurnal dengan baik tetapi metode yang digunakan perusahaan yaitu metode kontrak selesai dimana metode ini belum sesuai dengan PSAK 34 tentang kontrak kontruksi. Menurut peneliti perusahaan lebih tepat menggunakan metode persentase penyelesaian. Di lain pihak Thoyyibah (2017) menjelaskan bahwa metode yang digunakan perusahaan yang diteliti dalam pengakuan pendapatan adalah metode kontrak selesai.

Metode tersebut dapat digunakan hanya untuk pelaksanaan kontrak kontruksi yang masa penyelesainnya kurang dari satu periode akuntansi. Dalam kenyataannya, pelaksanaan sebuah proyek dapat memakan waktu lebih dari satu periode akuntansi. Sehingga metode kontrak selesai yang diterapkan kurang tepat karena timbul masalah dalam pengakuan pendapatan diakhir periode akuntansi atau pada akhir tahun yang sama dapat saja mengakibatkan kesahalan dalam perhitungan laba yang akan berpengaruh terhadap penyajian dalam laporan keuangan. Penelitian yang dilakukan Tikupadang dkk (2016) perusahaan yang diteliti menggunakan metode persentase penyelesaian sebagai pengakuan pendapatan. Menurut peneliti konsep ini sudah efektif dan memadai karena dengan konsep ini pengguna laporan keuangan akan mengetahui berapa besar laba yang dihasilkan dari operasi normal perusahaan. Sehingga tidak ada hal yang ditutupi menyangkut laba rugi perusahaan. Laporan laba rugi yang disajikan terdiri dari pengurangan atas pendapatan kontrak yang diperoleh selama satu periode akuntansi dengan beban-beban yang secara terperinci.

Terkait dengan pengakuan pendapatan sesuai dengan PSAK No. 34 yang membahas tentang laporan keuangan perusahaan kontruksi, peneliti mengambil objek di PT Arteri Cipta Rencana. Perusahaan tersebut merupakan salah satu perusahaan kontruksi terbesar di Indonesia mengenai proyek jalan dan jembatan. Fenomena penelitian yang terkait pada kontrak kerja dan pengakuan pendapatan. Dimana laporan keuangan perusahaan jasa kontruksi dibuat diawal kontrak. Beberapa kasus mengenai waktu pelaksanaan dan biaya tidak sesuai dengan kontrak awal akibat faktor-faktor yang terjadi dilapangan, sehingga pengakuan pendapatan perusahan belum jelas. Kesesuain dengan PSAK No. 34 sangat berpengaruh dalam pendapatan perusahaan kontruksi.

Mengingat kontrak kerja dan pengakuan pendapatan merupakan hal penting bagi laporan keuangan perusahaan kontruksi maka diharapkan menggunakan metode yang sesuai. Dalam menyelesaikan suatu proyek mencapai jangka waktu yang berbeda maka metode yang digunakan juga berbeda. Dengan adanya perbedaan dalam metode pengakuan pendapatan, maka perusahaan konstruksi dihadapkan pada permasalahan bagaimana menentukan pengakuan pendapatan yang tepat, terutama pada proyekproyek jangka panjang, sehingga laporan keuangan dapat disajikan secara wajar 
sesuai dengan kinerja perusahaan pada periode tersebut. Perhitungan laba yang akurat dan laporan keuangan yang wajar sesuai dengan standar akuntansi keuangan yang berlaku membuat perusahaan dapat mengambil keputusan yang tepat bagi perusahaan.

Berdasarkan uraian latar belakang yang dijelaskan, masih belum adanya konsistensi atas penerapan PSAK No. 34 dalam pengakuan pendapatan pada perusahaan jasa kontruksi, maka peneliti berniat melakukan penelitian mengenai "Analisis Penerapan PSAK 34 dalam Pengakuan Pendapatan Perusahaan Jasa Kontruksi pada PT Arteri Cipta Rencana"

\section{TINJAUAN PUSTAKA}

\subsection{Teori Konsep Penandingan (Matching Concept Theory)}

Konsep Penandingan pertama kali dikemukakan oleh Paton \& Littleton pada tahun 1940. Teori ini mencakup pendapatan dan biaya dalam alporan keuangan. Menurut Warren dkk (2008:24) konsep penandingan adalah suatu konsep akuntansi dimana semua pendaptan yang dihasilkan harus dibandingkan dengan biaya-biaya yang ditimbulkan untuk memperoleh laba dari pendaptan untuk jangka waktu tertentu.

Konsep penandingan merupakan praktek akuntansi dimana perusahaan mengakui pendapatan dan beban terkait dalam periode yang sama. Perusahaan melaporkan pendapatan bersamaan dengan biaya yang dihasilkan. Hal utama mengapa perusahaan menggunakan konsep ini adalah untuk memastikan keuntungan yang diperoleh maupun kerugian yang jika ada selama suatu periode akuntansi. Konsep ini sangat penting untuk mengukur laba bersih dengan tepat.
Pada umumnya diakui bahwa pendapatan dan laba diperoleh sepanjang seluruh tahapan dari siklus operasi yaitu, selama penerimaan pesanan, produksi, penjualan, dan penagihan, dengan adanya kesulitan dalam mengalokasikan pendapatan dan laba ke tahapan yang berbeda dari siklus operasi, akuntan menggunakan prinsip realisasi untuk memililih "kejadian penting" (critical event) dalam siklus tersebut untuk penentuan waktu pendapatan dan pengakuan laba. Kejadian penting tersebut dipilih untuk mengindikasikan kapan perubahan tertentu dalam aktiva dan kewajiban dapat dipertanggungjawabkan secara memadai (Saeddah, 2016).

Dalam Konsep Penandingan (Matching Concept), pendapatan dengan biaya merupakan satu faktor penting dalam mengukur dan menilai kinerja perusahaan. Penerapan dari konsep ini dapat digunakan dalam memberikan informasi mengenai pengukuran dan pengakuan pendaptan, pecatatan biaya dan proses penandingan dari pendapatan dengan biaya tersebut (Iskandar, 2001).

Untuk menentukan periode akuntansi yang tepat, akuntan perlu menggunakan Akuntasi Dasar Kas atau Cash Basis dan Akuntansi Dasar Akrual atau Acrual Basis. Akuntansi dasar kas adalah metode pengakuan pendapatan dimana pendapatan dan beban dilaporkan dalam laporan laba rugi pada periode kas telah diterima atau telah dibayar. Besarnya laba bersih atau rugi yang dihasilkan dari selisih antara pendaptan dengan beban, akan mencerminkan jumlah bersih uang kas yang dihasilkan (net income) atau jumlah bersih kas yang dikeluarkan (net loss). Akuntansi dasar akrual merupakan 
metode dimana pendapatan dilaporkan dalam laporan laba rugi pada saat dimana pendapatan itu dihasilkan, dengan Akuntansi Dasar Akrual bebanbeban yang terkait dengan penciptaan pendapatan haruslah dilaporkan dalam periode yang sama dimana pendapatan tersebut juga diakui.

Pengeluaran beban yang diakui dalam laporan laba rugi berlandaskan atas dasar hubungan langsung antara biaya yang timbul dengan pos penghasilan tertentu yang diperoleh. Hubungan biaya dengan penghasilan melibatkan secara bersamaan atau gabungan anatra penghasilan dan beban. Sehingga suatu laporan keuangan yang disajikan harus mempertemukan secara layak anatra biaya-biaya yang dikeluarkan dengan pendapatan yang diperoleh dalam satu periode akuntansi yang sama.

Perbedaan antara konsep penandingan dengan konsep akrual terletak pada periodenya. Konsep akrual menyatakan bahwa perusahaan mengakui pendapatan dan pengeluaran ssat terjadi, dimana konsep akrual jatuh pada periode yang sama. Konsep penandingan dapat jatuh pada dua periode yang berbeda. Prinsip-prinsip akuntansi yang berlaku mempersyaratkan penggunaan dasar akrual tersebut. Akan tetapi, usaha jasa yang kecil boleh saja menggunakan dasar kas karena mereka mempunyai sedikit piutang dan uatang usaha. Bagi mereka, dasar kas akan menghasilkan laporan keuangan yang mirip dengan yang disajikan menurut dasar akrual (Simbolon, 2010).

Menurut Firman (2013) konsep penandingan terbagi atas 2 yaitu Direct atau Product Matching dan Indirect atau Periode Matching. Direct atau Product
Matching merupakan konsep yang mengabaikan beberapa masalah antara lain biaya yang belum bisa dikaitkan langsung dengan produk itu sehingga dalam konsep ini semua biaya lain diluar produk atau jasa itu dianggap sebagai aktiva yang dialihkan ke periode yang akan datang. Indirect atau Periode Matching dilakukan anatara hasil yang diperoleh dengan seluruh biaya yang dikeluarkan atau dibebankan selama periode dimana digunakan bukan berdasarkan waktu perolehan atau pembayaran ini disebut biaya periodik. Melalui pencocokan pengeluaran dan pendapatan, laporan keuangan dapat mewakili hasil yang lebih akurat. Teori ini membantu menghindari penyimpangan dalam posisi keuangan dan meningkatkan kualitas laporan keuangan.

\subsection{Teori Legitimasi (Legitimacy Theory)}

Teori Legitimasi pertama kali dikenalkan oleh Dowling dan Pfeffer (1975). Teori ini berfokus pada interkasi antara perusahaan dan masyarakat. Menurut Dowling dan Pfeffer, legitimasi adalah hal yang penting bagi organisasi, batasan-batasan yang ditekankan oleh norma-norma dan nilai-nilai sosial, dan reaksi terhadapa batasan tersebut mendorong pentingnya analisi perilaku organisasi dengan memperlihatkan lingkungan. Legitimasi dapat dianggap sebagai menyamakan persepsi atau asumsi bahwa tindakan yang dilakukan oleh suatu entitas adalah merupakan tindakan yang diinginkan, pantas ataupun sesuai dengan sistem norma, nilai, kepercayaan dan definisi yang dikembangkan secara sosial (Suchman, 1995).

Menurut Hasan (2017) Teori Legitimasi diterima dengan 
menunjukkan kinerja perusajaan yang sesuai atas penilain sosial, teori legitimasi menyatakan kinerja lingkungan yang lemah dapat meningkatkan ancaman legitimasi sosial perusahaan, sehingga mendorong perusahaan untuk melakukan luas pengungkapan dalam laporan tahunan, semua perusahaan pada akhirnya memberikan output dari operasinya kepada masyarakat, baik melalui distribusi ekonomi maupun manfaat sosial. Praktik tanggung jawab sosial dan luas pengungkapan sosial yang dilakukan perusahaan dapat dipandang sebagai suatu usaha memenuhi harapan-harapan masyarakat terhadap perusahaan.

Lindblom (1994) menunjukkan bahwa cara perusahaan dapat mempertahankan atau mendapatkan kembali legitimasi mereka di mata masyarakat adalah dengan mengungkapkan informasi tentang kinerja sosial dan lingkungan mereka. Adams et al (1998) berpendapat bahwa teori legitimasi penting dalam menjelaskan motivasi untuk pengungkapan sosial perusahaan bahkan di lingkungan yang berbeda khususnya di negara-negara Eropa kontinental, serta negara-negara Amerika. Deegan dan Rankin (1997) menunjukkan bahwa perubahan dalam praktik pengungkapan lingkungan didorong oleh upaya organisasi untuk melegitimasi operasi mereka, bergantung pada asumsi bahwa berbagai kelompok memang menggunakan informasi lingkungan yang terkandung dalam laporan tahunan.

Brown dan Deegan (1998) berpendapat bahwa media dapat menjadi sangat efektif dalam mengarahkan keprihatinan masyarakat tentang kinerja lingkungan organisasi tertentu (dari teori pengaturan media).
Ketika masalah tersebut muncul, organisasi akan merespons dengan meningkatkan tingkat pengungkapan informasi lingkungan dalam laporan tahunan (dari teori legitimasi). Hasil penelitian menunjukkan bahwa untuk sebagian besar industri yang diteliti, tingkat perhatian media yang lebih tinggi secara signifikan terkait dengan tingkat pengungkapan lingkungan laporan tahunan yang lebih tinggi. Hooghiemstra (2000) berpendapat bahwa pengungkapan sosial dan lingkungan merupakan respons terhadap tekanan publik dan perhatian media. Perusahaan menggunakan pengungkapan sosial sebagai strategi untuk mengubah persepsi publik tentang legitimasi perusahaan.

Menurut Mousa \& Hassan (2015) Teori Legitimasi dapat dianggap sebagai kerangka kerja konseptual yang didasarkan pada keberadaan hubungan sosial dan yang dapat dipertukarkan antara perusahaan dan masyarakat. Kerangka kerja ini bertujuan untuk menjelaskan mengapa perusahaan dapat terlibat dalam pengungkapan sosial dan lingkungan tertentu, dan bagaimana mereka melakukan itu, serta, apa dampak pengungkapan lingkungan terhadap publik dan masyarakat. Perilaku perusahaan terhadap masyarakat dapat mengidentifikasi jenis hubungan di antara mereka apakah itu kontribusi atau kerusakan, jika perusahaan tidak memikul tanggung jawab sosial dan lingkungannya. Oleh karena itu, teori legitimasi dapat didefinisikan sebagai penalaran logis dalam bentuk prinsip-prinsip luas yang ditetapkan oleh mana praktik pengungkapan lingkungan dapat dijelaskan atau dapat didasarkan. 
Teori legitimasi menyebutkan bahwa legitimasi merupakan faktor penting bagi perusahaan dalam rangka mengembangkan perusahaan ke depan. Hal-hal yang berkaitan dengan etika bisnis, perhatian dan pengembangan kinerja karyawan, dampak terhadap lingkungan perusahaan turut berkontribusi dalam meningkatkan legitimasi. Dengan demikian maka kepedulian perusahaan terhadap lingkungan yang kemudian ditunjukkan melalui environmental disclosures, diharapkan dapat meningkatkan legitimasi dan berdampak baik untuk jangka panjang perusahaan (Fashikhah dkk, 2018).

\subsection{Proyek Kontruksi}

Proyek adalah suatu usaha untuk mencapai suatu tujuan tertentu yang dibatasi oleh waktu dan sumber daya yang terbatas ehingga pengertian proyek konstruksi adalah suatu upaya untuk mencapai suatu hasil dalam bentuk bangunan atau infrastruktur, Mutmainah (2018). Proyek kontruksi menggunakan sumber daya seperti manajemen untuk mencapai tujuan yang optimal dari proyek tersebut. Manajemen meliputi fisik kontruksi, biaya dan waktu yang telah ditetapkan. Dalam proyek kontruksi perencanaan manajemen berperan hanya $20 \%$ kemudian sisanya manajemen pelaksanaaan yang melakukan pengendalian biaya dan waktu proyek.

Tumembow dkk

menjelaskan proyek konstruksi adalah satu rangkaian kegiatan yang hanya satu kali dilaksanakan dan umumnya berjangka pendek. Dalam rangkaian kegiatan tersebut, ada suatu proses yang mengelola sumber daya proyek menjadi suatu hasil kegiatan yang berupa bangunan.SÉpiTiga karateristik proyek konstruksi adalah:

a. Proyek bersifat unik, keunikan dari proyek konstruksi tidak pernah terjadi rangkaian kegiatan yang sama persis (tidak ada proyek identic, yang adalah proyek sejenis), proyek bersifat sementara, dan selalu melibatkan grup pekerja yang berbeda-beda.

b. Membutuhkan sumber daya (resources), setipa proyek konstruksi membutuhkan sumber daya dalam penyelesaiannya, yaitu pekerja dan sesuatu (uang, mesin, metoda, material). Pengorganisasian semua sumber daya tersebut dilakukan oleh manajer proyek.

c. Membutuhkan organisasi, setiap organisasi mempunyai keragaman tujuan di mana di dalamnya terlibat sejumlah individu dengan ragam keahlian, ketertarikan, kepribadian dan juga ketidakpastian. Langkah awal yang harus dilakukan oleh manajer proyek adalah menyatukan visi menjadi satu tujuan yang telah ditetapkan oleh organisasi.

\subsection{Kontrak Kerja}

Mutmainah

mengemukakan tentang jenis-jenis kontrak kontruksi menurut Keppres 80 tahun 2003 terbagi atas tiga yaitu berdasarkan bentuk imbalan, berdasarkan jangka waktu pelaksanaan dan berdasarkan jumlah penggunaan barang dan jasa. Berdasarkan bentuk imbalan terbagi atas 6 jenis yaitu:

a. Kontrak Lump Sum, Keppres 80 tahun 2003 menguraikan bahwa kontrak lump sum adalah kontrak pengadaan barang/jasa atas penyelesaian seluruh pekerjaan dalam batas waktu tertentu, dengan jumlah harga yang pasti dan tetap, dan semua resiko yang mungkin terjadi dalam proses 
penyelesaian pekerjaan sepenuhnya

ditanggung oleh penyedia barang/jasa.

b. Harga Satuan, kontrak harga satuan adalah kontrak pengadaan barang/jasa atas penyelesaian seluruh pekerjaan dalam batas waktu tertentu, berdasarkan harga satuan yang pasti dan tetap untuk setiap satuan/unsur pekerjaan dengan spesifikasi teknis tertentu, yang volume pekerjaannya masih bersifat perkiraan sementara, sedangkan pembayarannya didasarkan pada hasil pengukuran bersama atas volume pekerjaan yang benar-benar telah dilaksanakan oleh penyedia barang/jasa.

c. Kontrak Gabungan Lump Sum dan Harga Satuan adalah kontrak yang merupakan gabungan dari kontrak lump sum dan kontrak harga satuan dalam satu pekerjaan yang diperjanjikan.

d. Kontrak Terima Jadi (Turn Key) adalah kontrak pengadaan barang/jasa pemborongan atas penyelesaian seluruh pekerjaan dalam batas waktu tertentu dengan jumlah harga pasti dan tetap sampai seluruh bangunan/konstruksi, peralatan dan jaringan utama maupun penunjangnya dapat berfungsi dengan baik sesuai dengan kriteria kinerja yang telah ditetapkan.

e. Kontrak Persentase képiadalah kontrak pelaksanaan jasa konsultansi di bidang konstruksi atau pekerjaan pemborongan tertentu, dimana konsultan yang bersangkutan menerima imbalan jasa berdasarkan persentase tertentu dari nilai pekerjaan fisik konstruksi/ pemborongan tersebut. is isep: f. Kontrak Payung digunakan dalam hal pekerjaan yang akan dilaksanakan secara berulang dengan spesifikasi yang pasti namun volume dan waktu pesanan belum dapat ditentukan. Kontrak Payung digunakan dalam Pengadaan Barang/Jasa (PBJ) misalnya pengadaan obat tertentu pada rumah sakit, jasa boga, jasa layanan perjalanan (travel agent), atau pengadaan material. Kontrak Payung pada Jasa Konsultansi digunakan untuk mengikat Penyedia Jasa Konsultansi dalam periode waktu tertentu untuk menyediakan jasa, dimana waktunya belum dapat ditentukan. Penyedia Jasa Konsultansi yang diikat dengan Kontrak Payung adalah Penyedia Jasa Konsultansi yang telah memenuhi/lulus persyaratan yang ditetapkan. Kontrak Payung digunakan misalnya untuk Pengadaan Jasa Konsultansi dalam rangka penasihatan hukum, penyiapan proyek strategis nasional, dan penyiapan proyek dalam rangka kerjasama pemerintah dan badan usaha. isinp:

Berdasarkan jangka waktu pelaksanaan:

a. Tahun tunggal ispeis Kontrak tahun tunggal adalah kontrak pelaksanaan pekerjaan yang mengikat dana anggaran untuk masa 1 (satu) tahun

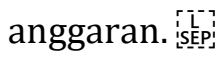

b. Tahun jamakisepikontrak tahun jamak adalah kontrak pelaksanaan pekerjaan yang mengikat dana anggaran untuk masa lebih dari 1 (satu) tahun anggaran yang dilakukan atas persetujuan oleh menteri keuangan untuk pengadaan yang dibiayai APBN, Gubernur untuk pengadaan yang dibiayai APBD 


Propinsi, Bupati/Walikota untuk
pengadaan yang dibiayai APBD
Kabupaten/kota. istep:

Berdasarkan jumlah pengguna barang/jasa:

a. Kontrak pengadaan tunggal adalah kontrak antara satu unit kerja atau satu proyek dengan penyedia barang/jasa tertentu untuk menyelesaikan pekerjaan tertentu dalam waktu tertentu.

b. Kontrak pengadaan bersama adalah kontrak antara beberapa unit kerja atau beberapa proyek dengan penyedia barang/jasa tertentu untuk menyelesaikan pekerjaan tertentu sesuai dengan kegiatan bersama yang jelas dari masing- masing unit kerja dan pendanaan bersama yang dituangkan dalam kesepakatan bersama.

\subsection{Pengakuan Pendapatan}

Pendapatan merupakan penghasilan yang timbul dari aktivitas perusahaan yang biasa dikenal dengan sebutan yang berbeda seperti penjualan, penghasilan jasa, bunga, deviden, royalty dan sewa, sebaliknya aktiva yang diperoleh dari pembelian, hasil pinjaman dan tambahan modal tidak bisa dikatakan sebagai menaikan pendapatan (Thoyyibah, 2017). Menurut Ankarath dkk, (2012: 117) dalam Nurjanah (2016) Pendapatan adalah kenaikan imbalan ekonomis selama periode akuntansi dalam bentuk arus kas masuk atau peningkatan asset, atau penurunan liabilitas yang menyebabkan peningkatan di dalam ekuitas, selain darpada yang terkait iuran dan peserta ekuitas. Istilah pendapatan (income) meliputi baik pendapatan maupun keuntungan yang didefinisikan di dalam Kerangka untuk Penyusunan dan
Penyajian Laporan Keuangan.

Pendapatan (revenue) yang timbul dari rangkaian kegiatan biasa entitas. Pendapatan dapat timbul dari sumber seperti penjualan barang dagangan, profesi jasa, imbalan royalty, imbalan dari franchise, imbalan manajemen, dividen, bunga dan langganan. Keuntungan tidak timbul dari kegiatan bisnis utama dan meliputi laba atas penghentian asset tidak lancar, transaksi kembali saldo dalam mata uang asing, atau nilai wajar penyesuaian terhadap aset keuangan dan aset non keuangan.

Menurut PSAK No. 23 menjelaskan bahwa pendapatan hanya meliputi arus masuk bruto dari manfaat ekonomik yang diterima dan dapat diterima oleh entitas untuk entitas itu sendiri. Jumlah yang ditagih untuk kepentingan pihak ketiga, seperti pajak pertambahan nilai dan pajak penjualan, bukan merupakan manfaat ekonomik yang mengalir keentitas dan tidak mengakibatkan kenaikan ekuitas. Oleh karena itu, hal tersebut harus dikeluarkan dari pendapatan. Hal yang sama berlaku dalam hubungan keagenan, arus masuk bruto manfaat ekonomik mencakup jumlah yang ditagih untuk kepentingan prinsipak dan tidak mengakibatkan kenaikan ekuitas entitas. Jumlah yang ditagih atas nama prinsipal bukan merupakan pendapatan. Sebaliknya, pendapatan adalah jumlah komisi yang diterima.

Pengertian atau definisi pendapatan berbeda dengan pengakuan pendapatan. Menurut Kieso et al (2007) bahwa pendapatan diakui pada saat direalisasi atau dapat direalisasi. Pendapatan direalisasi apabila barang dan jasa ditukar dengan kas atau klaim atas kas (piutang). Pendapatan dapat direalisasi apabila aktiva yang diterima 
dalam pertukaran segera dapat dikonversi menjadi kas atau klaim atas kas dengan jumlah yang diketahui. Dihasilkan Pendapatan dihasilkan (earned) apabila entitas bersangkutan pada hakikatnya telah menyelesaikan apa yang seharusnya dilakukan untuk mendapat hak atas manfaat yang dimiliki oleh pendapatan itu. Dalam kenyataan praktek akuntansi, pengakuan pendapatan suatu perusahaan untuk periode tertentu dapat terjadi pada saat sebelum atau sesudah penjualan. Pengakuan adalah pencatatan jumlah rupiah secara resmi kedalam sistem akuntansi sehingga jumlah tersebut terefleksi dalam statement keuangan, dengan demikian suatu jumlah yang memenuhi definisi pendapatan tidak dengan sendirinya jumlah tersebut diakui (dicatat secara resmi) sebagai pendapatan (Suwardjono, 2005).

Kieso (2010: 93) menetapkan prinsip-prinsip pengakuan pendapatan bahwa pendapatan diakui pada saat direalisasi atau dapat direalisasi dan pada saat diperoleh. Pendapatan direalisasi bila barang dan jasa dipertukarkan untuk kas atau klaim atas kas/piutang. Pendapatan dapat direalisasi bila aktiva yang diterima segera dapat dikonversi pada jumlah kas atau klaim atas kas yang diketahui. Pendapatan dihasilkan bila kesatuan itu sebagian besar telah menyelesaikan apa yang seharusnya dilakukan agar berhak atas manfaat yang diberikan dari pendapatan, yakni bila proses mencari laba telah selesai atau sebenarnya telah selesai.

Menurut Kieso et al (2007) ada 2 metode dalam pengakuan pendapatan jasa kontruksi yaitu:

1. Metode Kontrak Selesai (Completed Contract Method). Menurut metode ini, pengakuan pendapatan dan laba kotor diakui pada saat kontrak diselesaikan. Dengan metode ini perusahaan kontraktor melakukan pengakuan pendapatan secara sekaligus saat kontrak sudah rampung, sehingga pendapatan dan beban/biaya sudah diketahui secara pasti. Metode pengakuan pendapatan dengan kontrak selesai dapat digunakan hanya pada saat kontrak jangka pendek.

\section{Laba Kotor = Nili Kontrak Provek - Biayz Yang Tela Dikcluartan}

\section{Gambar 1. Perhitungan Metode Kontrak Selesai}

2. Metode Persentase Penyelesaian (Percentage of Completion Method). Metode pengakuan pendapatan yang mengakui pendapatan, biaya dan laba kotor diakui setiap periode berdasarkan kemajuan proses konstruksi, yaitu presentase penyelesaian, biaya konstruksi ditambah laba kotor yang dihasilkan sampai hari ini diakumulasi dalam sebuah akun persediaan (konstruksi dalam proses) dan termin diakumulasi dalam akun kontrak persediaan (tagihan atas konstruksi dalam proses). Metode ini bertujuan adalah mengukur tingkat kemajuan dalam istilah biaya, unit maupun nilai tambah.

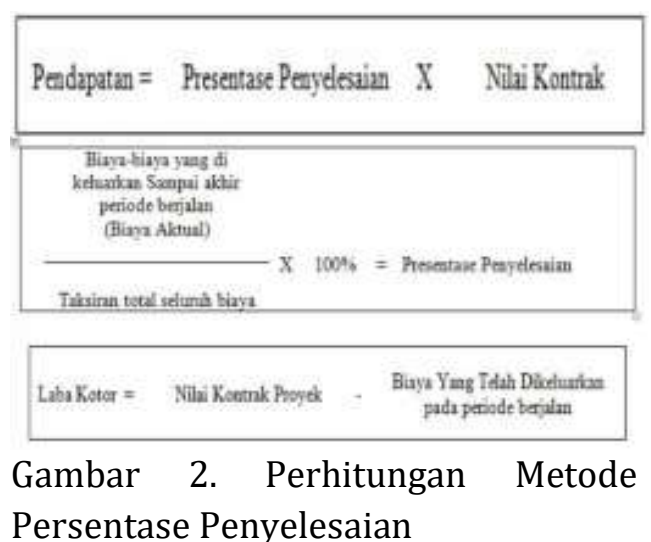

Persentase Penyelesaian 
Stice et al (2004) mengemukakan bahwa ada dua metode yang dapan digunakan untuk tingkat persentase penyelesaian pada perusahaan kontruksi. Dua metode yang dimaksud adalah ukuran input (input measures) dan ukuaran output (output measures). Ukuran input dibuat dalam hubungannya denga biaya usaha atau usaha yang dilakukan untuk suatu kontrak. Ukuran ini didasarkan pada hubungan yang ditetapkan atau diasumsikan antara satu unit input dengan prosuktivitas. Ukuran ini meliputi metode biaya ke baiya (cost to cost method) yang banyak digunakan dalam beberapa variasi dari metode upaya yang dikeluarkan. Ukuran output dibuat dalam hal hasil yang dicapai, termasuk dalam kategori ini adalah metode-metode yang didasarkan pada unit yang diproduksi, tahapan-tahapan kontrak yang dicapai, dan nilai tambah. Misalnya jika sebuah kontrak tersebut menggunakan unit output, seperti jumlah kilometer jalan panjang jalan, maka ukuran penyelesaiannnya adalah rasio dari jumlah kilometer yang diselesaikan terhadap total kilometer yang disebutkan dalam kontrak. Arsitek dan insinyur kadang diminta untuk mengevaluasi pekerjaan dan mengestimasikan berapa persentase penyeselesaian dari suatu pekerjaa. Estimasi-estimasi ini pada kenyataannya adalah ukuran output dan biasanya didasarkan pada kemajuan fisik yang dibuat atas suatu kontrak.

\subsection{PSAK No. 34}

Kontrak konstruksi adalah suatu kontrak yang dinegosiasikan secara khusus untuk konstruksi suatu aset atau suatu kombinasi aset yang berhubungan erat satu sama lain atau saling tergantung dalam hal rancangan, teknologi, dan fungsi atau tujuan pokok penggunaan. Suatu kontrak konstruksi mungkin dinegosiasikan untuk membangun sebuah aset tunggal seperti jembatan, bangunan, bendungan, pipa, jalan, kapal, dan terowongan. Kontrak konstruksi juga berkaitan dengan sejumlah aset yang berhubungan erat atau saling tergantung satu sama lain dalam hal rancangan, teknologi, dan fungsi atau tujuan pokok penggunaan; kontrak seperti ini misalnya, konstruksi kilang-kilang minyak atau bagian-bagian lain yang kompleks dari pabrik atau

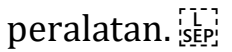

Biaya kontrak meliputi biaya-biaya yang dapat diatribusikan pada suatu kontrak selama periode sejak tanggal kontrak itu diperoleh sampai dengan penyelesaian akhir kontrak. Akan tetapi, biaya-biaya yang berhubungan langsung dengan suatu kontrak dan terjadi untuk memperoleh kontrak juga dimasukkan sebagai bagian dari biaya kontrak jika biaya-biaya ini dapat diidentifikasi secara terpisah dan dapat diukur secara andal dan kemungkinan besar kontrak tersebut dapat diperoleh. Jika biayabiaya yang terjadi untuk memperoleh kontrak diakui sebagai beban pada periode terjadinya, maka biaya-biaya tersebut tidak dimasukkan dalam biaya kontrak ketika kontrak tersebut diperoleh pada periode berikut. iscep?

Jika hasil kontrak konstruksi dapat diestimasi secara andal, maka pendapatan kontrak dan biaya kontrak yang berhubungan dengan kontrak konstruksi diakui masing-masing sebagai pendapatan dan beban dengan memerhatikan tahap penyelesaian aktivitas kontrak pada tanggal akhir periode pelaporan. iLئi

Pengakuan pendapatan dan beban dengan memerhatikan tahap penyelesaian suatu kontrak sering 
disebut sebagai metode persentase penyelesaian. Menurut metode ini, pendapatan kontrak dihubungkan dengan biaya kontrak yang terjadi dalam mencapai tahap penyelesaian tersebut, sehingga pendapatan, beban, dan laba yang dilaporkan dapat diatribusikan menurut penyelesaian pekerjaan secara proporsional. Metode ini memberikan informasi yang berguna mengenai cakupan aktivitas kontrak dan kinerja selama suatu periode.

Dalam metode persentase penyelesaian, pendapatan kontrak diakui sebagai pendapatan dalam laba rugi pada periode akuntansi di mana pekerjaan dilakukan. Biaya kontrak biasanya diakui sebagai beban dalam laba rugi pada periode akuntansi di mana pekerjaan yang berhubungan dilakukan. Namun, setiap ekspektasi selisih lebih total biaya kontrak terhadap total pendapatan kontrak segera diakui sebagai ičspeban.

Tahap penyelesaian suatu kontrak dapat ditentukan dalam berbagai cara. Entitas menggunakan metode yang mengukur secara andal pekerjaan yang dilakukan. Bergantung pada sifat kontrak, metode tersebut antara lain meliputi proporsi biaya kontrak yang terjadi untuk pekerjaan yang dilaksanakan sampai tanggal perhitungan dibandingkan dengan estimasi total biaya kontrak; ; sEp isurvei atas pekerjaan yang telah dilaksanakan; dan penyelesaian suatu bagian secara sik dari pekerjaan kontrak. Pembayaran berkala dan uang muka yang diterima dari para pelanggan sering kali tidak mencerminkan tahap penyelesaian. is.p?

Jika hasil kontrak kontruksi tidak dapat diestimasi secara andal maka pendapatan diakui hanya sebesar biaya yang telah terjadi sepanjang biaya tersebut diperkirakan dapat dipulihkan; dan biaya kontrak diakui sebagai beban pada periode terjadinya. Taksiran rugi pada kontrak konstruksi segera diakui sebagai beban.

Selama tahap awal suatu kontrak sering terjadi hasil kontrak tidak dapat diestimasi secara andal. Walaupun demikian, dimungkinkan entitas akan memulihkan biaya kontrak yang terjadi. Oleh karena itu, pendapatan kontrak diakui hanya sepanjang biaya yang terjadi diharapkan dapat dipulihkan. Disebabkan hasil kontrak tidak dapat diestimasi secara andal, maka tidak ada laba yang diakui. Tetapi, walaupun hasil kontrak tidak dapat diestimasi secara andal, dimungkinkan total biaya kontrak melebihi total pendapatan kontrak. Dalam hal ini, setiap selisih lebih total biaya kontrak terhadap total pendapatan kontrak diakui segera sebagai beban.

\section{METODE PENELITIAN}

\subsection{Teknik Analisis Data}

Analisis data adalah proses mencari dan menyusun secara sistematis data yang diperoleh dari hasil wawancara, catatan lapangan dan dokumentasi. Metode analisi yang digunakan dalam penelitian ini adalah metode deskriptif analisis. Dalam hal ini data-data yang ditemukan dipaparkan secara apa adanya. Kemudian dikumpulkan lalu disusun agar dapat diteliti dan dibandingkan dengan teori yang relevan yang berhubungan dengan masalah yang dibahas kemudian akhirnya diambil suatu kesimpulan (Maulinda, 2019).

Menurut Milles and Huberman, analisis data tertata dalam situs ditegaskan bahwa kolom pada sebuah matriks tata waktu disusun dengan jangka waktu, dalam susunan tahapan, sehingga dapat dilihat kapan gejala 
tertentu terjadi. Prinsip dasarnya adalah kronologi. Berikut tahapan dalam analisis data tertata, Pertama, Membangun sajian, pada tahap ini cara yang mudah bergerak maju adalah memecah-mecah inovasi ke dalam komponen- komponen atau aspek-aspek khusus, dengan menggunakan ini sebagai baris matriks. Kolom matriks adalah jangka-jangka waktu, dari penggunaan awal sampai penggunaan nanti. Jika terjadi perubahan dalam komponen selama jangka waktu itu, kita dapat memasukkan deskripsi singkat dari perubahan itu (Miles dan Huberman, 2007: 173-174).

Kedua, Memasukkan data. Pada tahap ini, penganalisis sedang mencari perubahan-perubahan dalam inovasi itu, komponen demi komponen. Perubahanperubahan itu dapat ditempatkan dalam catatan-catatan lapangan wawancara dengan para pengguna inovasi yang sudah terkode, yang ditanyai secara khusus apakah mereka telah membuat suatu yang sudah terkode dalam format buku inovasi. Kelanjutan penyelidikan menurut adanya bagian-bagian yang telah ditambah, didrop, diperbaiki, digabungkan, atau diseleksi untuk digunakan. Dalam beberpa hal dapat mengacu pada bukti-bukti dokumenter (Miles dan Huberman, 2007: 174).

Ketiga, Menganalisis data. Pada tahap ini, penganalisis dapat memahami lebih dalam mengenai apa yang terjadi dengan mengacu kembali pada aspekaspek lain dari catatan lapangan, khususnya apa lagi yang dikatakan orang mengenai perubahan itu atau alasanalasannya (Miles dan Huberman, 2007: 177). Analisis data dalam penelitian kualitatif dilakukan sejak sebelum memasuki lapangan, selama memasuki lapangan, dan setelah selesai dari lapangan. Analisis data dilakukan pada saat pengumpulan data berlangsung, dan setelah selesai pengumpulan data dalam periode tertentu.

Miles and Huberman dalam Sugiyono (2008: 237), megemukakan aktivitas dalam analisis data kualitatif harus dilakukan secara terus menerus sampai tuntas, sehingga datanya sudah jenuh. Analisis data dalam penelitian ini dilaksanakan pada saat pengumpulan data dalam periode tertentu. Pada saat wawancara, peneliti sudah melakukan analisis terhadap jawaban yang diwawancarai. Apabila jawaban yang disampaikan oleh orang yang diwawancarai atau informan setelah dianalisis dirasa kurang memuaskan, maka peneliti akan melanjutkan pertanyaan lagi, sampai tahap tertentu sehingga diperoleh data atau informasi yang lebih kredibel.

Untuk menyajikan data agar mudah dipahami, maka langkah-langkah anlisis data yang digunakan dalam penelitian ini adalah Analysis Interactive Model dari Miles dan Huberman, yang membagi langkah-langkah dalam kegiatan analisis data dengan beberapa bagian yaitu pengumpulan data, reduksi data (data reduction), penyajian data (data display), dan penarikan kesimpulan atau verifikasi (conclutions).

\section{a. Pengumpulan Data}

Data yang didapat dari hasil wawancara, observasi dan dokumentasi dicatat pada catatan lapangan yang terdiri atas 2 bagian yaitu bagian deskriptif dan bagian reflektif. Pengertian catatan deskriptif yaitu catatan alami, (merupakan catatan mengenai apa yang disaksikan, didengar, dilihat dan dialammmi sendiri oleh peneliti tanpa adanya penafsiran dan pendapat dari peneliti terhadap 
fenomena yang dialaminya). Catatan reflektif adalah catatan yang isinya kesan, pendapat, komentar serta tafsiran peneliti mengenai apa penemuan yang dijumpai. Selain itu merupakan bahan rencana pengumpulan data untuk tahap selanjutnya.

\section{b. Reduksi Dataispep}

Berdasarkan catatan lapangan yang terdiri dari hasil wawancara, observasi dan dokumen dari pihak yang terkait dalam PT Arteri Cipta Rencana maka selanjutnya dilakukan reduksi data. Reduksi data adalah suatu bentuk analisis yang menajamkan, menggolongan, mengarahkan, membuang data yang tidak perlu dan mengorganisasi data dengan cara sedemikian rupa sehingga simpulan final dapat ditarik dan diverifikasi (Miles dan Huberman, 2007: 16). Peneliti akan memfokusnya hasil redusi data sesuai rumusan masalah dalam penelitian ini yaitu mengenai kontrak kerja kerja dan pengakuan pendapatan perusahaan sesuai dengan PSAK 34.

\section{c. Penyajian Data}

Setelah reduksi data maka selanjutnya adalah penyajian data. Sajian data adalah suatu rangkaian organisasi informasi yang memungkinkan kesimpulan riset dapat dilakukan. Penyajian data dimaksudkan intuk menemukan pola-pola yang bermakna serta memberikan kemungkinan adanya penarikan simpulan serta memberikan tindakan (Miles dan Huberman, 2007: 84). Menurut Sutopo (dalam Harsono, 2008: 169) menyatakan bahwa sajian data berupa narasi kalimat, gambar/skema, jaringan kerja dan tabel sebagai narasinya. Dalam hal ini peneliti memfokuskan pada penelitian mengenai kontrak kerja dan pengakuan pendapatan pada perusahaan kontruksi. Hasil dari penyajian data mampu memudahkan peneliti dalam upaya pemaparan dan penegasan kesimpulan.

\section{d. Penarikan Kesimpulan}

Penarikan kesimpulan merupakan bagian dari sutu kegiatan konfigurasi yang utuh (Miles dan Huberman, 2007: 18). Kesimpulan- kesimpulan juga diverifikasi selama penelitian berlangsung. Kesimpulan ditarik semenjak peneliti menyususn pencatatan, pola- pola, pernyataanpernyataan, konfigurasi, arahan sebab akibat, dan berbagai proposisi (Harsono, 2008: 169). Dalam hal ini, peneliti berusaha dan berharap kesimpulan yang dicapai mampu menjawab rumusan masalah yang telah dirumuskan sejak awal yaitu yang berkaitan dengan kontrak kerja dan pengakuan pendapatan pada perusahaan kontruksi PT Arteri Cipta Rencana.

\subsection{Pengujian Keabsahan Data}

Teknik yang digunakan dalam pemeriksaan keabsahan data seperti yang dikemukakan oleh Moleong (2006: 327), adalah perpanjangan keikut sertaan, ketekunan pengamatan, triangulasi, pengecekan sejawat, analisi kasus negative, kecukupan refernsial, dan pengecekan dengan anggota yang terlibat dalam penelitian. Pengujian keabsahan data menggunakan empat criteria sebagaimana yang dikemukakan oleh Sugiyono (2008), yaitu: kredibilitas (credibility), keteralihan (transferability), kebergantungan/reliabilitas (dependability), dan kepastian/dapat dikonfirmasi (confirmability).

\section{a. Kepercayaan (credibility)}

Uji credibility atau validitas internal merupakan uji kepercayaan terhadap data hasil penelitian kualitatif 
yang dilakukan dengan perpanjangan pengamatan, peningkatan ketekunan dalam penelitian, triangulasi, diskusi dengan teman sejawat, analisis kasus negatif, dan member check. Menurut Sutopo (dalam Harsono, 2008: 173), triangulasi merupakan cara yang paling umum digunakan bagi peningkatan validitas dalam penelitian kualitatif. Ada dua jenis triangulasi ditambah stau review informan.

\section{b. Triangulasi Sumber}

Membandingkan data hasil pengamatan dengan data hasil wawancara, membandingkan apa yang dikatakan di depan umum dengan apa yang dikatakan secara pribadi, dan membandingkan wawancara dengan dokumen yang berkaitan. Pengecekan dilakukan kepada pihak-pihak yang terlibat dalam penerapan kontrak kerja dan pengakuan pendapatan pada PT Arteri Cipta Rencana.

\section{c. Triangulasi Metode}

Pengecekan derajat kepercayaan penemuan hasil penelitian beberapa teknik pengumpulan data dan pengecekan derajat kepercayaan beberapa sumber data dengan metode yang sama. Pengecekan dilakukan kepada pihak-pihak yang terlibat dalam penerapan kontrak kerja dan pengakuan pendapatan pada PT Arteri Cipta Rencana.

\section{d. Keteralihan (transferability)}

Keteralihan (transferability), pada dasarnya merupakan validitas eksternal pada penelitian kualitatif. Transferability perlu dilakukan orang lain yang telah mempelajari laporan peneliti (Sutama, 2010: 73). Orang lain, termasuk rekanrekan peneliti, para pembimbing atau promoter, dan para penguji akan membandingkannya dengan kepustakaan, wacana, penelitian, dan pengalamannya masing-masing.

\section{e. Kebergantungan/reliabilitas (dependability)}

Paradigma positivistic memandang reliabilitas temuan penelitian isçisebagai replikabilitas, yaitu kemampuan hasil penelitian untuk diulang yang dilakukan dengan teknik pengujian berbentuk parallel (Sutama, 2010: 73). Dependability dalam penelitian kualitatif disebut reliabilitas. Suatu penelitian dikatakan dependability apabila orang lain dapat mengulangi atau mereplikasi proses penelitian tersebut. Dalam penelitian kelaitatif, uji dependability dilakukan dengan cara malakukan audit terhadap keseluruhan proses penelitian. Caranya dilakukan oleh auditor yang independen atau pembimbing untuk mengaudit keseluruhan aktivitas peneliti dalam melakukan penelitian isEp?

\section{f. Kepastian/dapat dikonfirmasi (confirmability)}

Confirmability atau konfirmabilitas merupakan serangkaian langkah untuk mendapatkan jawaban apakah ada keterkaitan antara data yang sudah diorganisasikan dalam catatan lapangan dengan materi-materi yang digunakan dalam audit trail (Harsono, 2008: 176). Audit trail merupakan langkah diskusi analitik terhadap semua berkas data hasil penelitian, mulai berkas data penelitian sampai dengan transkip pelaporan, dilakukan dengan konfirmasi informasi secara langsung kepada nara sumber dan menghubungkan perolehan informasi satu sama lain.

Pengujian confirmability dalam penelitian kualitatif disebut dengan uji obyektifitas penelitian. Penelitian dikatakan obyektif apabila hasil penelitian disepakati oleh banyak orang. 
Dalam penelitian kualitatif, uji confirmability mirip dengan uji dependability, sehingga pengujiannya dapat dilakukan secara bersamaan. Uji confirmability adalah menguji hasil penelitian yang dikaitkan dengan proses yang dilakukan. Dalam penelitian ini mendeteksi kepastian variabel kontrak kerja dan pengakuan pendapatan dalam catatan lapangan dengan materi-materi dalam audit trail.

\section{HASIL DAN PEMBAHASAN}

\subsection{Pokok - Pokok PSAK 34 Revisi 2010}

Terkait dengan PSAK 34 yang telah direvisi tahun 2010, maka perlu terlebih dahulu untuk mengetahui garis besar apa saja yang menjadi pokok pokok aturan dalam PSAK 34. Tujuan Pernyataan ini adalah untuk menggambarkan perlakuan akuntansi pendapatan dan biaya yang berhubungan dengan kontrak konstruksi. Oleh karena sifat dari aktivitas yang dilakukan pada kontrak konstruksi, tanggal saat aktivitas kontrak mulai dilakukan dan tanggal saat aktivitas tersebut diselesaikan biasanya jatuh pada

Periode akuntansi yang berlainan.

Oleh karena itu, persoalan utama dalam akuntansi kontrak konstruksi adalah alokasi pendapatan kontrak dan biaya kontrak pada periode di mana pekerjaan konstruksi tersebut dilaksanakan. Pernyataan ini menggunakan kriteria isepepengakuan yang diatur dalam Kerangka Dasar Penyusunan dan Penyajian Laporan Keuangan untuk menentukan kapan pendapatan dan biaya suatu kontrak konstruksi diakui sebagai pendapatan dan beban dalam laporan laba rugi komparatif.
Pendapatan kontrak diukur pada nilai wajar dari imbalan yang diterima atau akan diterima. Pengukuran pendapatan kontrak dipengaruhi oleh beragam ketidakpastian yang bergantung pada hasil dari peristiwa di masa depan. Estimasi sering kali perlu untuk direvisi sesuai dengan realisasi dan hilangnya ketidakpastian. Oleh karena itu, jumlah pendapatan kontrak dapat meningkat atau menurun dari satu periode ke periode berikutnya. Misalnya: išpep

a. Kontraktor dan pelanggan mungkin menyetujui isteppenyimpangan atau klaim yang meningkatkan atau menurunkan pendapatan kontrak pada periode setelah periode di mana kontrak pertama kali disetujui; is ip:

b. Nilai pendapatan yang disetujui dalam kontrak dengan nilai tetap dapat meningkat karena ketentuanketentuan kenaikan biaya;

c. Nilai pendapatan kontrak dapat menurun karena denda yang timbul akibat keterlambatan kontraktor dalam penyelesaian kontrak tersebut; atauis:

d. Jika dalam kontrak harga tetap terdapat harga tetap per unit ouput, pendapatan kontrak meningkat jika jumlah unit meningkat.

Menurut Farmuzi (2015), Standar Akuntansi Keuangan secara khusus mengatur tentang pengakuan pendapatan dan biaya kontrak dengan menerbitkan sebuah penyataan PSAK No. 34 tentang Akuntansi Kontrak Konstruksi. Tujuan PSAK No. 34 adalah untuk menggambarkan perlakuan akuntansi pendapatan dan biaya yang berhubungan dengan kontrak konstruksi, Dalam PSAK No. 34 (IAI, 2010, h.34.8), tentang pengakuan pendapatan dan biaya kontrak yaitu jika 
hasil kontrak konstruksi dapat diestimasi secara andal, maka pendapatan kontrak yang berhubungan dengan kontrak konstruksi diakui masing-masing sebagai pendapatan dan beban dengan memperhatikan tahap penyelesaian aktivitas kontrak pada tanggal akhir periode pelaporan. Taksiran rugi pada kontrak konstruksi tersebut diakui sebagai beban kontrak. Ikatan Akuntansi Indonesia (2010, h.34.9) dalam PSAK No. 34, Pengakuan pendapatan dan beban dengan memperhatikan tahap penyelesaian suatu kontrak sering disebut sebagai metode persentase penyelesaian.

Menurut metode ini, pendapatan kontrak dihubungkan dengan biaya kontrak yang terjadi dalam mencapai tahap penyelesaian tersebut, sehingga pendapatan, beban dan laba yang dilaporkan dapat diatribusikan menurut penyelesaian pekerjaan secara proporsional.

Biaya Kontrak Konstrusi Menurut PSAK NO 34 (2010: 34), biayasuatu kontrak konstruksi terdiri atas: Biaya yang berhubungan langsung dengan kontrak tertentu,Biaya yang dapat diatribusikan pada aktivitas kontrak pada umumnya dan dapat dialokasikan ke kontrak tersebut dan Biaya lain yang secara khusus dapat ditagihkan ke pemberi kerja sesuai isi kontrak. Pengakuan pendapatan dalam PSAK 34 pada kontrak kontruksi terdiri atas dua metode yaitu metode kontrak selesai dengan metode persentase penyelesaian. Metode tersebut digunakan berdasarkan periode proyek. Metode kontrak selesai mengakui pendapatan pada saat kontrak diselesaikan yang digunakan pada periode jangka pendek atau kurang dari 1 tahun. Metode persentase penyelesaian mengakui pendapatan sejalan dengan kontrak sampai proyek yang dikerjakan selesai dimana periode yang digunakan adalah periode jangka panjang atau lebih dari satu tahun yang biasa disebut dengan kontrak linear. Berikut adalah metode pengakuan pendapatan dalam kontrak kontruksi:

\section{a. Metode Kontrak Selesai}

Rangkuti (2008), mengatakan bahwa metode kontrak selesai biasanya digunakan perusahaan yang mempunyai kontrak jangka pendek atau proyek yang memiliki resiko tidak dapat diestimasi secara andal.

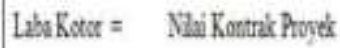
Buxa Yaug Téas Diketarkan

\section{b. Metode Persentase Penyelesaian}

Menurut Erlinadiansyah (2009), mengatakan bahwa metode persentase penyelesaian adalah metode yang mengakui pendapatan, biaya, dan laba kotor sesuai dengan persentase pekerjaan yang diselesaikan dalam tiap periode. Sejalan dengan itu Novianti (2014) menjelsakan, metode pengakuan pendapatan dengan persentase penyelesaian adalah metode pengakuan yang biasanya digunakan oleh perusahaan yang memiliki kontrak jangka panjang, dimana jangka waktunya lebih dari satu periode akuntansi. Metode persentase penyelesai merupakan salah satu metode yang digunakan untuk mengakui pendapatan pada perusaan konstruksi. Metode ini telah menjadi metode resmi untuk pengakuan pendapatan perusaanperusaan konstriksi yang ada di Indonesai. Terbukti metode ini menjadi pedoman pencatatan laporan keuangan bagi perusaan kostruksi dalam wujud PSAK 34 (Fajrianto, 2019). 

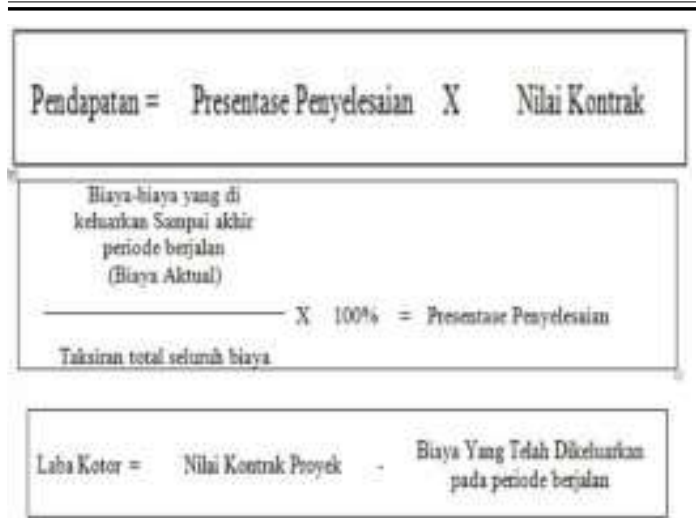

\subsection{Penerapan PSAK 34 dalam Pengakuan Pendapatan Jasa Kontruksi pada PT Arteri Cipta Rencana}

Proses pendapatan proyek PT Arteri Cipta Rencana diawali dengan proses tender dimana perusahaan akan mendapatkan proyek dari pemerintah jika menang tender. Jika perusahaan terpilih maka PPK melakukan finalisasi dan menandatangani kontrak pelaksanaan pekerjaan. Penandatanganan kontrak dilakukan 14 hari setelah diterbitkan Surat Penunjukan Barang Dan Jasa (SPPBJ) yang diterbitkan oleh PPK dan setelah perusahaan menyerahkan jaminan pelaksanaan, dan memeriksa konsep kontrak meliputi substansi serta membubuhkan paraf pada setiap lembar dokumen kontrak. Setelah proyek selesai perusahaan mengajukan permintaan kepada PPK untuk penyerahan pekerjaan, kemudian dilakukan penilaian oleh PPK atas pekerjaan yang telah diselesaikan, perusahaan melakukan penyerahan pekerjaan secara bertahap yaitu: Provisional Hand Over ( $\mathrm{PHO}$ ) yaitu penyerahan pekerjaan yang dilakukan setelah masa kontrak berakhir, dan yang ke dua yaitu: Final Hand Over (FHO) penyerahan yang dilakukan setelah masa pemeliharaan (retensi) berakhir yang tercantum di dalam kontrak
(Tikupadang, 2016). Perusahaan PT Arteri Cipta Rencana sebagai salah satu perusahaan yang bergerak dibidang kontruksi menjalankan proyek dalam dua jenis yakni proyek jangka panjang dan proyek jangka pendek.Penelitian ini bertujuan untuk mengetahui kesesuaian antara analisis pendapatan dan penggunaan metode pengakuan pendapatan PSAK 34 pada perusahaan PT Arteri Cipta Rencana yang berfokus pada proyek di Sorong, Papua Barat periode 2016 2018. Penelitian ini dilakukan dengan mengumpulkan data laporan keuangan periode 2016 - 2018 dan juga Peneliti melakukan wawancara kepada site engineering, selaku penanggungjawab jalannya proyek selama 3 periode tersebut. Berikut adalah proyek yang dimaksud:

Tabel 2

Daftar Proyek

\begin{tabular}{|c|c|c|}
\hline Proyek & Periode & Anggaran \\
\hline $\begin{array}{l}\text { Pengawasan } \\
\text { Jalan dan } \\
\text { Jembatan Ruas } \\
\text { Nasional dan } \\
\text { Strategis } \\
\text { Sorong } 1\end{array}$ & $\begin{array}{l}\text { Maret - } \\
\text { Oktober } \\
(2016)\end{array}$ & $\begin{array}{c}\text { Rp. } \\
2.401 .400 .000\end{array}$ \\
\hline $\begin{array}{l}\text { Pengawasan } \\
\text { Jalan dan } \\
\text { Jembatan Ruas } \\
\text { Nasional dan } \\
\text { Strategis } \\
\text { Sorong } 4 \\
\end{array}$ & $\begin{array}{c}\text { Februari - } \\
\text { Desember } \\
\text { (2017) }\end{array}$ & $\begin{array}{l}\text { Rp. } \\
2.302 .355 .000\end{array}$ \\
\hline $\begin{array}{c}\text { Pengawasan } \\
\text { Teknis } \\
\text { Pembangunan } \\
\text { Jalan Maybrat } 5\end{array}$ & $\begin{array}{l}\text { Maret - } \\
\text { Oktober } \\
(2018)\end{array}$ & $\begin{array}{l}\text { Rp. } \\
979.142 .450\end{array}$ \\
\hline
\end{tabular}

Berdasarkan pemaparan sebelumnya bahwa laporan keuangan perusahaan konstruksi lebih efektif jika 
menggunakan metode kontrak selesai. Karena metode kontrak selesai mengakui pendapatan secara langsung ketika proyekyang dikerjakan telah selesai. Sehingga dalam penentuan nilai untuk pendapatan tidak perlu lagi melakukan estimasi tidak ada resiko kesalahan dalam penyajian nilainya (Fajrianto, 2019).

Tabel 3 Daftar Rincian Beban Kontrak

\begin{tabular}{|c|c|c|c|}
\hline \multirow{2}{*}{ Beban Kontrak } & \multicolumn{3}{|c|}{ Rincian } \\
\cline { 2 - 4 } & $\mathbf{2 0 1 6}$ & $\mathbf{2 0 1 7}$ & $\mathbf{2 0 1 8}$ \\
\hline Upah & Rp. 1.244 .800 .000 & $\begin{array}{c}\text { Rp. } \\
1.049 .140 .000\end{array}$ & $\begin{array}{c}\text { Rp. } \\
536.289 .250\end{array}$ \\
\hline $\begin{array}{c}\text { Mobilisasi dan } \\
\text { Demobilisasi }\end{array}$ & Rp. 68.500.000 & Rp. 53.600.000 & Rp. 2.700.000 \\
\hline Perjalanan Dinas & Rp. 77.000.000 & Rp. 78.450.000 & $\begin{array}{c}\text { Rp. } \\
12.000 .000\end{array}$ \\
\hline Biaya Kantor & Rp. 112.125 .000 & Rp. 112.500 .000 & $\begin{array}{c}\text { Rp. } \\
61.590 .250\end{array}$ \\
\hline Biaya Pelaporan & Rp. 22.750 .000 & Rp. 26.800.000 & $\begin{array}{c}\text { Rp. } \\
11.550 .000\end{array}$ \\
\hline Biaya Akomodasi & Rp. 411.325 .000 & Rp. 367.000.000 & $\begin{array}{c}\text { Rp. } \\
126.000 .000\end{array}$ \\
\hline Total Beban & Rp. 1.936 .500 .000 & 1.887 .490 .000 & $\begin{array}{c}\text { Rp. } \\
750.123 .500\end{array}$ \\
\hline
\end{tabular}

Beban kontrak atau biaya-biaya yang dikeluarkan PT Arteri Cipta Rencana terbagi atas 2 yaitu biaya personil dan biaya non personil. Biaya personil yang dimaksud adalah upah atau jasa yang diberikan oleh perusahaan untuk mengawasi jalan maupun jembatan. Biaya personil terdapat upah tenaga ahli seperti site engineer, quality, quantity dan upah tenaga non ahli seperti administrasi dan office boy. Biaya selanjutnya adalah biaya non personil, yang termasuk biaya non personil adalah mobilisasi, demobilisasi, perjalanan dinas, biaya kantor, biaya pelaporan dan biaya akomodasi. 
Tabel 4

Perhitungan Metode Kontrak Selesai

\begin{tabular}{|c|c|c|c|}
\hline \multirow{2}{*}{ Periode } & Nilai Kontrak Setelah & \multicolumn{2}{|c|}{ Rincian } \\
\cline { 3 - 4 } & \begin{tabular}{c} 
PPN 10\% \\
\cline { 3 - 4 }
\end{tabular} & Total Biaya & $\begin{array}{c}\text { Laba Kotor } \\
\text { (Pendapatan- } \\
\text { Biaya) }\end{array}$ \\
\hline $\mathbf{2 0 1 6}$ & Rp. 2.183 .150 .000 & Rp. 1.936 .500 .000 & Rp. 246.650.000 \\
\hline $\mathbf{2 0 1 7}$ & Rp. 2.093 .050 .000 & Rp. 1.887 .490 .000 & Rp. 205.560 .000 \\
\hline $\mathbf{2 0 1 8}$ & Rp. 890.129 .500 & Rp. 750.123 .500 & Rp. 140.006 .000 \\
\hline
\end{tabular}

Tabel perhitungan metode kontrak selesai diatas memaparkan bahwa anggaran proyek 2016 dan 2017 adalah proyek dengan kualifikasi menengah yaitu $<2,5 \mathrm{M}$, sedangkan pada tahun 2018 kualifikasi anggaran kecil yaitu $<1 \mathrm{M}$. Hal ini membuat adanya anggaran dari 2017 ke 2018 tergolong kecil baik dari segi upah personil maupun upah non personil. Nilai kontrak setelah PPN yang direalisasikan kemudian dikurangi biaya hasilnya adalah laba kotor perusahaan yang diakui sebagai pendapatan.

Pada wawancara site engineer mengatakan bahwa kadang terjadi nego antara pekerja dengan perusahaan karena kontrak proyek dibuat pada saat memulai tender, selisih inilah yang perusahaan jadikan sebagai pendapatan perusahaan. Jika terjadi kerugian maka dilakukan subsidi silang, dimana proyek yang lain dengan anggaran yang lebih besar dapat meutupi kerugian proyek lain.

Berdasarkan hasil wawancara diketahui bahwa penerapan pengakuan pendapatan PSAK 34 pada periode 2016 - 2018 pada PT Arteri Cipta Rencana telah dilaksanakan sesuai dengan PSAK 34. Hal ini menunjukkan kepatuhan PT Arteri Cipta Rencana dalam menjalankan standar pelaporan keuangan yang baku. Dalam wawancara juga akuntan mengakui melakukan rekap laporan keuangan secara bertahap mulai dari jurnal, pembukuan sampai pendapatan. Narasumber mengatakan bahwa pelaporan dilakukan secara bertahap mulai dari pelaporan divisi proyek yang ada dilapangan lalu dilanjutkan ke kantor pusat. Resiko yang dapat terjadi jika menggunakan metode kontrak selesai yaitu terletak pada kontrak kerja karena rata - rata anggarannyakecil. Hal ini kadang menjadi beban kontrak. Sesuai dengan teori matching concept dimana Konsep penandingan merupakan praktek akuntansi dimana perusahaan mengakui pendapatan dan beban terkait dalam periode yang sama. Perusahaan melaporkan pendapatan bersamaan dengan biaya yang dihasilkan. Hal utama mengapa perusahaan menggunakan konsep ini adalah untuk memastikan keuntungan yang diperoleh maupun kerugian yang jika ada selama suatu periode akuntansi.

Perusahaan mengakui pendapatannya tidak selalu menunggu sampai pekerjaan selesai dilaksanakan, tetapi besarnya pendapatan konstruksi yang diperoleh perusahaan 
ditentukan berdasarkan persentase pekerjaan atau nilai produksi yang telah diselesaikan. Pendapatan yang diterima ketika prestasi pekerjaan telah dicapai dapat dinilai dengan menggunakan dokumen- dokumen pendukung kegiatan perusahaan seperti: Berita Acara Kemajuan Pekerjaan, dan Sertifikat Bulanan (Monthly Certificate/MC) atau invoice. Monthly Certificate sendiri merupakan sertifikat bulanan pembayaran prestasi pekerjaan dalam bentuk dokumen internal proyek yang berisikan perhitungan besaran pembayaran prestasi pekerjaan penyedia jasa, untuk diajukan kepada pengguna jasa guna mendapatkan pembayarandalam bentuk mata uang (Tikupadang, 2016).

\section{PENUTUP}

\subsection{Simpulan}

Berdasarkan hasil penelitian dan pembahasan diketahui bahwa penerapan PSAK 34 pada PT Arteri Cipta Rencana telah menjalankan kontrak proyek dengan berurutan sesuai dengan peraturan tender yang berlaku dan merealisaikan anggaran dengan tepat. Pengakuan pendapatan dan beban yang dilakukan PT Arteri Cipta Rencana telah sesuai dengan PSAK 34 dimana pengkuan pendapatan atas kontrak kontruksi dilakukan dengan menggunakan metode kontrak selesai pada periode jangka pendek pada laporan keuangan 2016 - 2018. Hal ini telah sesuai dengan PSAK 34 yang berlaku di Indonesia.

Proyek jangka pendek dengan menggunakan metode kontrak selesai meminimalis adanya resiko kesalahan dalam melakukan estimasi terhadap nilai yang ditentukan. Laporan keuangan dianggap telah memenuhi kriteria kualitas laporan keuangan dengan baik.

\subsection{Saran}

Keterbatasan penelitian ini terletak pada proyek yang diteliti tidak menyeluruh dan tidak ada proyek jangka panjang pada tahun 2016 - 2018 yang diteliti. Kebijakan yang diterapkan oleh perusahaan dalam mengakui pendapatannya sudah baik, tapi karena keterbatasan penelitian maka peneliti menyarankan agar PT Arteri Cipta Rencana menggunakan metode yang sesuai dengan proyek jangka panjang maupun proyek jangka pendek yang sesuai dengan PSAK 34. Adapun pengakuan pendapatan yang diakui sebelum kontrak selesai sebaiknya dilakukan dengan konsisten sesuai dengan peraturan yang berlaku.

\section{DAFTAR PUSTAKA}

Adams, C. A., Coutts, A. and Harte, G. 1995. Corporate Equal Opportunities (Non-disclosure). British Accounting Review 27 (2): 87-108.

Brown, N and Deegan. 1998. The Public Disclosure of Environmental Performance Information-a Dual Test of Media Agenda Setting Theory and Legitimacy Theory. Accounting and Business Research 29 (1): 21-41.

Darmayanti, Elmira Febri. 2016. Analisis Pengakuan Pendapatan pada Perusahaan Kontruksi.

Deegan, C., and Rankin. 1997. The Materiality of Environmental Information to Users of Accounting Reports. Accounting, Auditing and Accountability Journal 10 (4): 562583.

Erlinadiansyah, TY. 2009. Analisis Metode Pengakuan Pendapatan dengan 
Pendekatan Persentase

Penyelesaian dalam Rangka

Menyajikan Laporan Keuangan pada PT Pembangunan Perumahan (Persero). Skripsi, UNAIR.

Fajrianto, Wahyu. 2019. Analisis Penerapan Metode Persentase Pentelesaian dan Metode Kontrak Selesai dalam Menilai Kualitas Laporan Keuangan Perusahaan Kontruksi. Skripsi, UIN Alauddin Makassar.

Farmuzi, Aris, dkk. 2015. Analisis Pengakuan Pendapatan Perusahaan Kontruksi Proyek Bendungan Marangkayu pada PT. Luhribu Naga jaya Samarinsa. Jurnal Fakultas Ekonomi Universitas 17 Agustus 1945.

Fashikhah, Isnani dkk. 2018. Determinan Enviromental Disclosures Perusahaan Manufaktur di Indonesia dan Malaysia. Jurnal Akuntansi Indonesia 7 (1): 31-55.

Firman, Roswana. 2013. Teori Konservatisme \& Teori Matching Concept Akuntansi.

Harsono. 2008. Pengelolaan Perguruan Tinggi. Yogyakarta: Pustaka Pelajar.

Hasan, Hamida. 2017. Pengaruh Luas Pengungkapan Corporate Social Responsibility, Karakteristik Eksekutif, Kepemilikan Keluarga, Profitabilitas dan Corporate Governance terhadap Agresitivitas Pajak. Tesis, Universitas Hasanuddin Makassar.

Hooghiemstra, R. 2000. Corporate Communication and Impression Management-New Perspectives Why Companies Engage in Coporate Social Reporting. Journal of Business Ethics (27): 55-68.

Iskandar, Bernard. 2001. Kesesuaian Penerapan Konsep Penandingan (Matching Concept) PendaptanBiaya pada Perusahaan
Pengembang Real Estat " $X$ " Surabaya dengan PSAK NO. 44. Skripsi, Universitas Airlangga.

Japar, Sugiarto Raharjo. 2018. Prinsip Prinsip Kontrak Kontruksi indonesia. Jurnal Mimbar Yustitia 2 (2).

Kieso, Donald E., Jerry J. Weygant \& Terry D. Warfield. 2007. Intermediate Accounting. Jakarta: Erlangga.

Kieso, Donald E. 2010. Intermediate Accounting Thirteen Edition. Hoboken: John Wiley \& Sons.

Kuncoro, Mudrajad. 2013. Metode Riset untuk Bisnis \& Ekonomi. Jakarta: Erlangga.

Lindblom, C. K. 1994. The Implication of Organizational Legitimacy for Corporate Social Performance and Disclosure. Paper Presented at The Critical Perspectives on Accounting Conference, New York.

Lumingkewas, Valen Abraham. 2013. Pengakuan Pendapatan dan Beban atas Laporang Keuangan pada PT. Bank Sulut. Jurnal EMBA 1 (3): 199-206.

Maulinda, Mela. 2019. Analisis Penerapan Akuntansi Kontrak Kontruksi dalam Penyajian Laporan Keuangan pasa CV. Abdi Karya Pratama Bandar Lampung. Skripsi, Universitas Islam Negeri Raden Intan Lampung.

Miles, Matthew B \& A. Michael Huberman. 2007. Qualitative Data Analysis (terjemahan). Jakarta: UI Press.

Moleong, Lexy J. 2006. Metodologi Penelitian Kualitatif. Bandung: PT. Remaja Rosdakarya.

Mousa, Gehan A \& Naser T. Hassan. 2015. Legitimacy Theory and Environmental Practice: Short Notes. International Journal of Business and Statistical Analysis 2 (1): 41-53. 
Mutmainah. 2018. Analisa Kontrak Kerja Kontruksi pada Proyek Rehab Bengkel Ruang Widyaiswara, Penyuluh dan Lab. IT. Di Dinas Pangan, Tanaman Pangan dan Hortikultura Kalimantan Timur. Jurnal Teknik Sipil 1 (6).

Nainggolan, Adolpino \& Riza Satria Nugraha. 2017. Analisis Perlakuan Akuntansi Pendapatan dan Beban Jasa Kontruksi dalam Rangka Perhitungan Laba Kotor PT. Djasa Uber Sakti. Jurnal Ilmiah Akuntansi dan Ekonomi 1 (2).

Novianti, MD \& Lailatul. 2014. Penerapan Metode Pengakuan Pendapatan Kontrak Jangka Panjang pada PT Adhikarya Jaya Mandiri. Jurnal Ilmu dan Riset Akuntansi 3 (8).

Nurianti. 2013. Analisi Pengakuan Pendapatan dan Beban pada CV. Gajah Benu Ulak Bosa Sintong (Rohil). Skripsi, Universitas Islam Negeri Sultan Syarif Kasim Riau Pekanbaru.

Nurjanah, Evi. 2016. Pengakuan Pendapatan dengan Metode Persentase Penyelesaian Berdasarkan PSAK NO. 34. Skripsi, Universitas Islam Negeri (UIN) Maulana Malik Ibrahim Malang.

Oroh, Pingkan Christin. 2013. Evaluasi Penerapan PSAK No. 34 (Revisi 2010) dalam Pengakuan dan Pengukuran Pendapatan Usaha Jasa Kontruksi pada CV. Surya Gemilang Utama. Jurnal EMBA 1 (4): 1845-1856.

Pernyataan Standar Akuntansi Keuangan (PSAK) No. 23 \& No. 34.

Pramurti, Fina Setya. 2016. Analisi Pengakuan Pendapatan Jasa Kontruksi pada CV. Indarchi Architect Team Klaten. Universitas Muhammadiyah Surakarta.
Rangkuti, Muhammad I. 2008. Pengakuan dan Pengukuran Perusahaan Jasa Kontruksi pada PT Pembangunan Perumahan (Persero) Cabang Medan. Usu eRepisitory.

Riswan, Yolanda Fatrecia Kesuma. 2014. Analisis Laporan Keuangan sebagai Dasar dalam Peniliaian Penelitian Kinerja Keuangan. Jurnal Keuangan Akuntansi \& Keuangan 5 (1).

Saeddah. 2016. Akuntansi tentang Prinsip dan Konsep Dasar Akuntansi.

Simatupang, Fitri Aulia. 2019. Pelaksanaan Perjanjian Paket Pekerjaan Konsultan antara Satuan Kerja Non Vertikal tertentu Perencanaan dan Pengawasan Jalan Nasional Provinsi Jambi dengan PT Arteri Cipta Rencana. JOM Fakultas Hukum Universitas Riau 6 (2).

Simbolon, Harry Andrian. 2010. Siklus Akuntansi: Penandingan \& Penyesuaian.

Stice, James D, Earl K. Stice \& K. Fred Skousen. 2004. Akuntansi Keuangan Menengah. Jakarta: Salemba Empat.

Suchman, M. C. 1995. Managing Legitimacy: Strategic and Institutional Approaches. Academy of Management Review, 20, 571610.

Sugiyono. 2008. Metodologi Penelitian Kuantitatif, Kualitatif dan R\&D. Bandung: CV Alfabeta.

Sugiyono. 2003. Metodologi Penelitian dan Bisnis. Bandung: CV Alfabeta.

Sugiyono. 2011. Metodologi Penelitian dan Bisnis. Bandung: CV Alfabeta.

Sutama. 2010. Metode Penelitian Pendidikan Kuantitatif, Kualitatif, PTK, R\&D. Surakarta: Fairuz Media. 
Suwardjono. 2005. Teori Akuntansi, Perekayasaan Pelaporan Keuangan Edisi 3. BPFE Yogyakarta.

Suwarti. 2009. Suatu Tinjauan Sistematik Hukum dalam peejanjian Pekerjaan Rehabilitasi Jembatan "TUGU" antara Balai Pelaksana Teknis Bina Marga Wilayah Sragen dengan CV. Cakra Kembang. Skripsi, Universitas Muhammadiyah Surakarta.

Thoyyibah, Lilik. 2017. Analisis Metode Pengakuan Pendapatan terhadap Kontrak Kontrksi. Skripsi, UIN Maulana Malik Ibrahim Malang.

Tikupadang, Feris Kristian, dkk. 2016. Analisis Penerapan Akuntansi Kontrak Kontruksi dalam Penyajian Laporan Keuangan pada PT. Sederhana Karya Jaya di Manado. Jurnal Berkala Ilmiah Efisiensi 16 (4).

Tumembow, Wiwie Yuliati dkk. 2016. Analisis Kontrak Kerja Owner terhadap Kontraktor (Studi Kasus: Perumahan Taman Mapanget Raya). Jurnal Sipil Statik 4 (5).

Warren, Carl S., James M Reeve \& Philip E. Fees. 2008. Pengantar Akuntansi. Jakarta: Salemba Empat.

Yastiar, Revany Widi. 2014. Pernyataan Standar Akuntansi Keuangan No. 34 yang Diterapkan dalam Pengakuan Pendapatan pada PT. Presta Berlima Kantor Cabang Semarang. 